\title{
Editorial
}

\section{The Society for Neuroscience 2009 Meeting Report, Part 1}

Amber Dance and Esther Landhuis

Alzheimer Research Forum

\section{AXONAL TRANSPORT NOT SO FAST IN NEURODEGENERATIVE DISEASE}

The long axons of neurons act as intracellular highways, with motor proteins shuttling their cargo up and down microtubule tracks. Block that traffic - by any number of ways - and the result is often feeble, dying neurons. The impairment of fast axonal transport (FAT) in a variety of neurodegenerative diseases was the theme at a mini-symposium held Sunday, 18 October 2009, at the Society for Neuroscience annual meeting in Chicago, Illinois [1].

"These diseases ... share several common characteristics," said Gerardo Morfini, who co-chaired the session with Gustavo Pigino. Both work at the University of Illinois in Chicago. A frequent pattern, Morfini said, is that defects in axonal transport and synapse function lead to a "dying back" axonal pathology, loss of connectivity between neurons, and, much later on, neuronal cell death.

Researchers recapped the impairment of FAT in models of Parkinson disease [2], Alzheimer's [3], and hereditary spastic paraplegia [4]. They discussed new studies as well. For example, Daryl Bosco of the University of Massachusetts in Worcester presented data showing that two proteins associated with amyotrophic lateral sclerosis (ALS) - superoxide dismutase 1 (SOD1) and Fused in Sarcoma (FUS) - inhibit FAT. Skip Binder of the Northwestern University Medical School in Chicago shared results on a phosphorylation site that regulates tau's interference in axonal trafficking. And, in a separate session on Huntington disease held October 20, Sarah Pollema of the University of Illinois at Chicago showed which part of polyglutamineexpanded huntingtin interferes with transport. (Hint: It's not where you might think.)

For their experiments, the scientists depended on North Atlantic squid (Loligo pealii), netted off the coast of the Marine Biological Laboratory in Woods Hole, Massachusetts, so researchers could harvest their giant axons. "This animal seems to have been created by nature for neuroscientists," quipped Morfini in a presentation last month at the André-Delambre Foundation Symposium on ALS in Québec City. Their giant axons are half a millimeter in diameter, and researchers can extrude the axoplasm "like a sausage," Morfini said, onto a microscope slide. They can then watch molecular motors cart material up and down the microtubules, and perfuse proteins and drugs to see if they affect transport.

SODI and FUS: Each blocks transport in its own way

Axonal transport has long been a topic of interest in ALS. Mutations in dynein cause motor neuron degeneration in mice [5]. And in a recent genomewide association study, researchers found an allele of kinesinassociated protein 3 (KIFAP3) that lengthened survival time among people with the disease [6].

Bosco, Morfini, and colleagues added SOD1 protein - mutations to the SOD1 gene are the most common cause of inherited ALS - to squid axoplasm. Wild-type protein had no effect, but G93A mutant SOD1 inhibited anterograde transport. Retrograde transport proceeded 
unimpeded. The same was true for other ALS-linked SOD1 mutants H46R, A4V, and G85R. To explore the mechanism by which SOD1 slowed transport, the researchers infused the squid axoplasm with various kinase inhibitors in addition to the mutant protein. They found that inhibiting p38 MAP kinase restored normal transport in the presence of mutant SOD1. To the authors, the data suggest that mutant SOD1 activates p38, which is known to phosphorylate kinesin, knocking the motor off the microtubules.

Mutant SOD1 is implicated in only 2 percent of ALS cases; other inherited mutations likely account for a further 8 percent, with the remaining instances currently thought to be sporadic. However, some scientists suspect wild-type SOD1 of involvement in motor neuron pathology in sporadic ALS, too, as mutations in the DNA sequence are not the only way to compromise a protein. Bosco suggested that the protein's structure could be modified in various ways in disease. The protein normally functions as a dimer, with an intramolecular disulfide bond and zinc and copper cofactors - but any of those characteristics could change in disease, she said. Altered wild-type SOD1 might be just as bad for motor neurons as the mutant forms.

Bosco hypothesized that antibodies raised to mutant SOD1 [7] might also interact with wild-type protein in people with sporadic ALS. Among CNS tissue samples from 10 people who died of sporadic ALS, she found that four stained positive with the mutant SOD1 antibodies. Four did not and a further two had no evident motor neurons to examine. The researchers are currently using mass spectrometry to discover which SOD1 modifications are present in the immunoreactive samples.

That evidence led Bosco to wonder if modified, wildtype SOD1 would also impede axonal trafficking as the mutants did. Sure enough, purified protein from the immunoreactive patient samples did slow FAT in the squid axoplasm.

Earlier this year, researchers linked a new gene to familial ALS. FUS is involved in RNA transcription, splicing, and transport [8,9]. When Bosco and colleagues added mutant FUS protein to squid axoplasm, they saw that both anterograde and retrograde transport slowed down. This contrasted with the effects of SOD1, which were solely on anterograde trafficking. The data suggest that FUS's effects on axonal transport may be mediated by a different mechanism than SOD1's.

\section{Tau: Presenting PAD}

It has been known for some time that tau polymers inhibit anterograde FAT. In previous work, Binder and colleagues discovered that deleting the amino terminus of tau - amino acids 2 through 18 - prevented its interference with axonal transport [10]. At the symposium, Binder reported on further research, led by former graduate student Nichole LaPointe, who is now at the University of California-Santa Barbara; Nick Kanaan, currently a post-doc in Binder's laboratory; and Morfini. Kanaan wondered if the 2-18 region of tau required the rest of the protein, as well, to inhibit transport. Accordingly, he synthesized a peptide with only those amino acids - and found that this amino-terminal region alone impeded FAT.

Like SOD1, tau exerts its effects on FAT via phosphorylation of the motors. Previously, the researchers found that inhibitors of glycogen synthase kinase-3 (GSK3) and protein phosphatase 1 (PP1) prevent tau from slowing transport. PP1 dephosphorylates GSK3, activating it to dephosphorylate kinesin, detaching the motor from its cargo. The amino terminus of tau corresponds to a consensus sequence for PP1 binding, and the researchers christened amino acids 2 through 18 the Phosphatase Activation Domain (PAD). They do not yet know if this domain directly interacts with PP1 or activates it indirectly, perhaps through an enzymatic cascade.

The PAD contains a phosphorylation site at tyrosine 18, and Kanaan suspected the presence or absence of this phosphate would affect axonal transport. He engineered a mutant with glutamate at position 18 to mimic phosphorylation, and found that the pseudophosphorylated protein did not inhibit FAT. Nor did purified, phosphorylated wild-type tau polymers. Therefore, Kanaan concluded, the PAD's effect on transport is mediated by phosphorylation at tyrosine 18 , and the unphosphorylated form is the one that blocks FAT, presumably through some interaction with PP1.

Binder suspects that in a healthy brain, the PAD is tucked away inside the tau protein, unable to interfere with transport. But when tau is altered in disease, the PAD may stick out. "Anything that presents the PAD region to the cell should inhibit anterograde transport," Binder said.

\section{Huntingtin: It's the Ps, not the Qs}

Morfini and colleagues previously showed that polyglutamine expanded huntingtin, as well as interferes 
with anterograde transport: It activates cJun N-terminal kinase 3 (JNK3) to phosphorylate kinesin, uncoupling the motor from its tracks [11]. Pollema, a graduate student in Morfini's and Brady's laboratories, shared her work on which part of huntingtin mediates this effect.

Disease-causing huntingtin harbors an excess of glutamine repeats. Pollema showed that the first exon of the polyQ-expanded protein, containing those repeats, was sufficient to inhibit transport. Yet right next to those glutamines, and also in exon 1, lies a string of prolines. Further along the sequence is a second prolinerich domain, or PRD. To determine which part of the exon slowed axonal traffic, Pollema infused squid axoplasm with exon 1, along with antibodies to block either the glutamate or proline sequences. She found that only the proline antibody prevented the inhibition, indicating that the PRDs, not the polyglutamine repeats themselves, were the culprits. Further confirming the results, she showed that short polyproline peptides were sufficient to inhibit transport.

In conclusion, Morfini wrote in an e-mail to ARF that it might someday be possible to correct axonal transport defects with drugs that modify kinase activity. Several such pharmaceuticals are making their way through clinical trials for a variety of cancers. "Correcting fast axonal transport deficits in neurodegenerative disease by modulating kinase activities appears a promising avenue of research," Morfini wrote. - Amber Dance.

\section{MOVE OVER, AGONISTS; MAKE WAY FOR MODULATORS}

At a satellite symposium, "Nicotinic Acetylcholine Receptors (nAChRs) as Therapeutic Targets," held days before the Society of Neuroscience's annual meeting in Chicago last month, clinical discussion of cognitive treatments focused largely on nAChR agonists. Clearly, though, the arena of potential compounds has expanded. Mirroring a trend seen in muscarinic AChR drug development, the newest $\mathrm{nAChR}$ compounds are positive allosteric modulators (PAMs), which avoid the neurotransmitter site and instead bind alternate regions on the nicotinic AChR.

Though PAMs have yet to strut their stuff in the clinic, many in the field suspect they have an edge over agonists. Nicotinic AChRs desensitize with repeated stimulation at the neurotransmitter binding site, so a nagging problem with agonists has been that they induce tolerance and thereby lose effectiveness over time.
In an overview of advances in $\alpha 7$ PAMs, John Dunlop of Wyeth Research in Princeton, New Jersey, noted that in preclinical studies, the efficacy profile for PAMs parallels that of agonists. $\alpha 7$ PAMs can correct deficits in sensory gating $[12,13]$ and prepulse inhibition [14]two noted endophenotypes that serve as electrophysiological biomarkers in schizophrenics. Modulators have also shown cognitive enhancement in vivo, for example, in rats subjected to water-maze learning tasks [15].

However, one perceived disadvantage of PAMs is their reliance on cholinergic transmission, which may already be sagging in Alzheimer's disease and other conditions. This could also be viewed as an advantage, some scientists say, because it means PAMs do not "create" additional signaling but rather amplify normal nAChR signaling - a feature that may be favorable for long-term use. Furthermore, some PAMs, namely those classified as Type 1, may do little for the tolerance problem that plagues agonists, because only Type 2 PAMs slow receptor desensitization, said Vince Simmon, CEO of Xytis, a private biotech company in Irvine, California. But Type 2 PAMs are a doubleedged sword in another way. In order to reduce desensitization rates, they gate large amounts of $\mathrm{Ca}^{2+}$, which could have neurotoxic effects, as was the case with Pfizer's PNU-120596 and Eli Lilly's ampakine drug LY-503430, Simmon said. Type 1 PAMs only induce a moderate, that is, two- to threefold, increase in $\mathrm{Ca}^{2+}$ influx and maintain the quick receptor desensitization, which implies they may be less potent as agonists but possibly better because they do not create extra signaling. All told, scientists said it is too early to predict whether the ideal $\alpha 7$ compound would be an agonist or a PAM.

Thus far, one $\alpha 7$ PAM has gained clearance from the U.S. Food and Drug Administration to enter clinical development. It is compound XY4083, made by Xytis. The company has published preclinical data on this Type 1 PAM [13] but did not present new findings at the recent $\mathrm{nAChR}$ symposium. Nor has it begun Phase I trials of the compound, despite having gained FDA approval for such studies in November 2008. "We are looking for financing and/or partnership," Simmon told ARF in a phone interview. The decision about which disease(s) to target would be made with a partner, but at this point the company is leaning toward standard-of-care therapy in schizophrenia as a first indication. "With schizophrenia, there are short-term tests that can be done for cognition, for example, sensory gating. Whereas in $\mathrm{AD}$, you have to do pretty long-term studies to see effects," Sim- 
mon said. At the nAChR symposium, posters described $\alpha 7$ PAMs in preclinical development at Johnson \& Johnson (JNJ-1930942), Abbott (A-716096), Roche (dimethylcyclopropyl-benzamides), and GlaxoSmithKline (PheTQS).

\section{Puff, puff}

A presentation by Paul Newhouse of the University of Vermont, Burlington, provided a respite from the flood of $\alpha$ numeric compound names. Rather than boosting cognitive function by tickling nAChRs with agonists or modulators, his team recruited people with mild cognitive impairment (MCI) for a pilot trial of a physiological nAChR substrate - nicotine itself.

Motivation for this trial came from earlier work by Newhouse and others showing that cholinergic mechanisms help mediate age-related shifts in the way our brains handle cognitive tasks. These studies tested predictions extending from the Resource Reduction Hypothesis, which presumes that reduced efficiency in lower-level core processes (e.g., attention, working memory, speed of memory) leads to higher-level impairments (e.g., decision making, language, problem solving). Researchers have found that people compensate for age-induced declines in core processes by increasingly shifting cognitive processing forward in the brain. As such, elders performing at the same level as younger people show more activity in frontal brain structures. Blockage of nicotinic or muscarinic AChRs with antagonists can reproduce this effect in young people, suggesting that the cholinergic system is involved in this caudal to frontal shift (aka the PASA effect).

On these grounds, Newhouse and colleagues simply asked whether nicotine, in this case offered through skin patches, would provide any measurable cognitive boost to MCI patients whose $\mathrm{nAChR}$ function is presumably better preserved than that of people with outright AD. Their study, which was funded by the National Institute on Aging (NIA), enrolled 74 non-smokers with amnestic MCI at three sites for a six-month doubleblinded study, followed by a six-month open-label extension. During the double-blinded phase, the treatment group showed improvement on various measures including delayed word recall accuracy, choice reaction time, and speed of memory. "If we saw cognitive improvement, we did not lose that effect over the relatively lengthy trial," Newhouse said. The study had no major drug-related adverse events, though the nicotine-treated group did end up with lower blood pressure. Curiously, the treatment effects were more prominent in ApoE4 homozygotes compared to people with the ApoE3 allele or just one copy of E4. Thirty of 70 participants in that MCI trial had at least one E4 allele. At the Cognitive Neuroscience Society's annual meeting held in San Francisco earlier this spring, UK researchers also reported E4 preferential benefit to young people (ages 18-30) treated with a nicotine nasal spray. In a separate trial presented by Newhouse at the nAChR symposium, nicotine improved several core cognitive deficits in non-smoking adolescents with attention deficit hyperactivity disorder (ADHD). And recently, Pfizer has moved varenicline (a nicotinic receptor partial agonist sold under trade name Chantix for smoking addiction) into a Phase II trial of mild to moderate AD patients. Esther Landhuis.

\section{REFERENCES}

[1] Morfini GA, Burns M, Binder LI, Kanaan NM, LaPointe N, Bosco DA, Brown RH, Brown H, Tiwari A, Hayward L, Edgar J, Nave KA, Garberrn J, Atagi Y, Song Y, Pigino G, Brady ST (2009) Axonal transport defects in neurodegenerative diseases. J Neurosci 29, 12776-12786.

[2] Morfini G, Pigino G, Opalach K, Serulle Y, Moreira JE, Sugimori M, Llinás RR, Brady ST (2007) 1-Methyl-4phenylpyridinium affects fast axonal transport by activation of caspase and protein kinase C. Proc Natl Acad Sci USA 104, 2442-2447.

[3] Pigino G, Morfini G, Atagi Y, Deshpande A, Yu C, Jungbauer L, Ladu M, Busciglio J, Brady S (2009) Disruption of fast axonal transport is a pathogenic mechanism for intraneuronal amyloid beta. Proc Natl Acad Sci USA 106, 5907-5912.

[4] Edgar JM, McLaughlin M, Yool D, Zhang SC, Fowler JH, Montague P, Barrie JA, McCulloch MC, Duncan ID, Garbern J, Nave KA, Griffiths IR (2004) Oligodendroglial modulation of fast axonal transport in a mouse model of hereditary spastic paraplegia. J Cell Biol 166, 121-131.

[5] Hafezparast M, Klocke R, Ruhrberg C, Marquardt A, AhmadAnnuar A, Bowen S, Lalli G, Witherden AS, Hummerich H, Nicholson S, Morgan PJ, Oozageer R, Priestley JV, Averill S, King VR, Ball S, Peters J, Toda T, Yamamoto A, Hiraoka Y, Augustin M, Korthaus D, Wattler S, Wabnitz P, Dickneite C, Lampel S, Boehme F, Peraus G, Popp A, Rudelius M, Schlegel J, Fuchs H, Hrabe de Angelis M, Schiavo G, Shima DT, Russ AP, Stumm G, Martin JE, Fisher EM (2003) Mutations in dynein link motor neuron degeneration to defects in retrograde transport. Science 300, 808-812.

[6] Landers JE, Melki J, Meininger V, Glass JD, Van Den Berg LH, van Es MA, Sapp PC, van Vught PW, McKenna-Yasek DM, Blauw HM, Cho TJ, Polak M, Shi L, Wills AM, Broom WJ, Ticozzi N, Silani V, Ozoguz A, Rodriguez-Leyva I, Veldink JH, Ivinson AJ, Saris CG, Hosler BA, Barnes-Nessa A, Couture N, Wokke JH, Kwiatkowski TJ, Ophoff RA, Cronin S, Hardiman O, Diekstra FP, Leigh PN, Shaw CE, Simpson CL, Hansen VK, Powell JF, Corcia P, Salachas F, Heath S, Galan P, Georges F, Horvitz HR, Lathrop M, Purcell S, Al-Chalabi A, Brown RH (2009) Reduced expression of the KinesinAssociated Protein 3 (KIFAP3) gene increases survival in spo- 
radic amyotrophic lateral sclerosis. Proc Natl Acad Sci USA 106, 9004-9009.

[7] Urushitani M, Ezzi SA, Julien JP (2007) Therapeutic effects of immunization with mutant superoxide dismutase in mice models of amyotrophic lateral sclerosis. Proc Natl Acad Sci USA 104, 2495-24500.

[8] Kwiatkowski TJ, Bosco DA, Leclerc AL, Tamrazian E, Vanderburg CR, Russ C, Davis A, Gilchrist J, Kasarskis EJ, Munsat T, Valdmanis P, Rouleau GA, Hosler BA, Cortelli P, de Jong PJ, Yoshinaga Y, Haines JL, Pericak-Vance MA, Yan J, Ticozzi N, Siddique T, McKenna-Yasek D, Sapp PC, Horvitz HR, Landers JE, Brown RH (2009) Mutations in the FUS/TLS gene on chromosome 16 cause familial amyotrophic lateral sclerosis. Science 323, 1205-1208.

[9] Vance C, Rogelj B, Hortobágyi T, De Vos KJ, Nishimura AL, Sreedharan J, Hu X, Smith B, Ruddy D, Wright P, Ganesalingam J, Williams KL, Tripathi V, Al-Saraj S, Al-Chalabi A, Leigh PN, Blair IP, Nicholson G, de Belleroche J, Gallo JM, Miller CC, Shaw CE (2009) Mutations in FUS, an RNA processing protein, cause familial amyotrophic lateral sclerosis type 6. Science 323, 1208-1211.

[10] Lapointe NE, Morfini G, Pigino G, Gaisina IN, Kozikowski AP, Binder LI, Brady ST (2009) The amino terminus of tau inhibits kinesin-dependent axonal transport: Implications for filament toxicity. J Neurosci Res 87, 440-451.

[11] Morfini GA, You YM, Pollema SL, Kaminska A, Liu K, Yoshioka K, Björkblom B, Coffey ET, Bagnato C, Han D, Huang CF, Banker G, Pigino G, Brady ST (2009) Pathogenic huntingtin inhibits fast axonal transport by activating JNK3 and phosphorylating kinesin. Nat Neurosci 12, 864-871.

[12] Hurst RS, Hajós M, Raggenbass M, Wall TM, Higdon NR, Lawson JA, Rutherford-Root KL, Berkenpas MB, Hoffmann WE, Piotrowski DW, Groppi VE, Allaman G, Ogier R, Bertrand S, Bertrand D, Arneric SP (2005) A novel positive allosteric modulator of the alpha7 neuronal nicotinic acetylcholine receptor: in vitro and in vivo characterization. $J \mathrm{Neu}$ rosci 25, 4396-4405.

[13] Ng HJ, Whittemore ER, Tran MB, Hogenkamp DJ, Broide RS, Johnstone TB, Zheng L, Stevens KE, Gee KW (2007) Nootropic alpha7 nicotinic receptor allosteric modulator derived from GABAA receptor modulators. Proc Natl Acad Sci USA 104, 8059-8064.

[14] Dunlop J, Lock T, Jow B, Sitzia F, Grauer S, Jow F, Kramer A, Bowlby MR, Randall A, Kowal D, Gilbert A, Comery TA, Larocque J, Soloveva V, Brown J, Roncarati R (2009) Old and new pharmacology: positive allosteric modulation of the alpha7 nicotinic acetylcholine receptor by the 5-hydroxytryptamine $(2 \mathrm{~B} / \mathrm{C})$ receptor antagonist SB-206553 (3,5-dihydro-5-methyl-N-3-pyridinylbenzo[1,2b:4,5-b']di pyrrole-1(2H)-carboxamide). J Pharmacol Exp Ther 328, 766-776.

[15] Timmermann DB, Grønlien JH, Kohlhaas KL, Nielsen EØ, Dam E, Jørgensen TD, Ahring PK, Peters D, Holst D, Chrsitensen JK, Malysz J, Briggs CA, Gopalakrishnan M, Olsen GM (2007) An allosteric modulator of the alpha7 nicotinic acetylcholine receptor possessing cognition-enhancing properties in vivo. J Pharmacol Exp Ther 323, 294-307. 